\title{
Pengaruh Lama Inkubasi dan Variasi Jenis Starter Terhadap Kadar Gula, Asam Laktat, Total Asam dan pH Yoghurt Susu Kedelai
}

\author{
Anna Muawanah \\ Program Studi Kimia \\ FST UIN Syarif Hidayatullah Jakarta
}

\begin{abstract}
Abstrak
Telah dilakukan penelitian tentang pembuatan yoghurt susu kedelai, untuk mengetahui pengaruh jenis starter terhadap perubahan kadar gula, asam laktat, total asam dan $\mathrm{pH}$ pada susu hasil fermentasi. Sebagai perlakuan dalam penelitian ini adalah variasi starter Lactobacillus bulgaricus dan Streptococcus thermophillus dan lama inkubasi. Parameter yang diuji meliputi Kadar gula, asam laktat dengan metode HPLC, total asam dengan titrasi dan $\mathrm{pH}$ dengan $\mathrm{pH}$ meter. Hasilnya menunjukkan bahwa Waktu inkubasi mempengaruhi penurunan $\mathrm{pH}$ dan kenaikan konsentrasi total asam. Perbandingan variasi jumlah dua starter yang digunakan tidak mempengaruhi proses perubahan komponen gula menjadi asam laktat. Data HPLC menunjukkan bahwa komponen gula adalah sukrosa dan laktosa yang konsentrasinya menurun selama inkubasi dari 0 jam sampai 8 jam. Jenis Asam yang dihasilkan adalah asam laktat, dimana konsentrasinya mengalami peningkatan 0 jam sampai 8 jam, terutama pada sampel yang perbandingan starternya 1:3.
\end{abstract}

Kata Kunci : Yoghurt susu kedelai, Streptococcus thermopillus, lactobacillus bulgaricus, HPLC

Abstract

The Influence of strain composition and incubation time to sugar and acid contains of soymilk yoghurt was investigated. The soymilk was fermented with Streptococcus thermopillus and lactobacillus bulgaricus on 1:3 and 3:1 ratio and incubated for 8 hours. Lactose, sucrose and lactic acid present in soymilk yoghurt were identified by HPLC methods. The result showed a decrease in lactose and sucrose contains at the first to $8^{\text {th }}$ hour, but the lactic acid contain was increase expecially in the sample with straint composition 1:3.

Key word: soymilk yoghurt, Streptococcus thermopillus, lactobacillus bulgaricus, HPLC

\section{PENDAHULUAN}

Seiring dengan meningkatnya pengetahuan, masyarakat kini tidak hanya memilih makanan/minuman yang bernilai gizi tinggi, tetapi juga yang dapat memberikan pengaruh dalam meningkatkan kesehatan. Salah satu jenis makanan/minuman kesehatan yang telah banyak dikembangkan adalah produk pangan yang mengandung spesies bakteri usus (probiotik).

Sediaan komponen sel mikroba dalam probiotik telah dilaporkan mempunyai pengaruh yang menguntungkan bagi kesehatan inangnya (Salminen, et al., 1949). Pengaruh positif dari probiotik diantaranya adalah untuk menjaga keseimbangan mikrofora usus yang berdampak dalam mencegah kanker kolon, serta dapat menurunkan kadar kolesterol serum darah yang berakibat pada menurunnya resiko terjadinya penyakit jantung koroner (Wollowski, et al., 1999 \& Kannel, et al., 1984).

Salah satu produk probiotik yang diproduksi industri pangan yaitu yoghurt. Yoghurt merupakan susu hasil fermentasi kultur bakteri asam laktat Lactobacillus bulgaricus dan Streptococcus thermophillus yang hidup secara simbiotik. Pengolahan susu menjadi yoghurt sudah lama dikenal di Indonesia, hanya saja masih berkisar pada lingkungan kota (Sirait, 1984). Yoghurt dapat dibuat dengan penambahan 1,5 - $3 \%$ kultur bakteri dengan inkubasi pada suhu $42-45{ }^{\circ} \mathrm{C}$ selama 3 jam. Produk yoghurt ditandai dengan analisis kadar 
asam laktatnya yang mencapai $1,9 \%$ dan $\mathrm{pH} 4$ - 4,2 (Belizt and Grosch, 1999).

Pada umumnya yoghurt diproduksi dengan menggunakan bahan dasar susu sapi. Penggunaan bahan dasar tersebut berakibat pada tingginya harga jual yoghurt di pasaran, sehingga tidak semua lapisan masyarakat dapat menjangkaunya. Oleh karena itu, perlu dicari bahan dasar lain dalam pembuatan yoghurt. Salah satu alternatif yang dapat dimanfaatkan

pada pembuatan yoghurt adalah susu kedelai.

Susu kedelai merupakan produk hasil ekstraksi kedelai dengan menggunakan air, yang mempunyai penampakan dan nilai gizi mirip dengan susu sapi. Susu kedelai mengandng serat kasar dan tidak mengandung kolesterol sehingga cukup baik bagi kesehatan. Selain itu susu kedelai tidak mengandung laktosa sehingga dapat dikonsumsi oleh penderita lactose intolerant (Muchtadi dan Sugiyono, 1991).

Susu kedelai dapat dibuat dengan memanaskan atau pasteurisasi suspensi kedelai pada titik didihnya selama 15-20 menit. Pemanasan tersebut juga berfungsi untuk menginaktifkan enzim lipoksigenase dan inhibitor protease. Di samping mengandung protein tinggi, susu kedelai merupakan sumber kalsium dan vitamin, sehingga dapat menggantikan susu sapi.

Selama proses pengolahan susu menjadi yoghurt, susu biasanya mengalami perubahan sifat kimia terutama kadar dan jenis gula, asam laktat dan total asamnya serta perubahan $\mathrm{pH}$ pada rentang waktu inkubasi tertentu. Penelitian ini dilakukan untuk mengetahui pengaruh lama inkubasi dan variasi jenis starter terhadap kadar gula, asam laktat, total asam dan $\mathrm{pH}$ yoghurt susu kedelai

Tahap-tahap pembuatan susu kedelai, secara umum meliputi perendaman kedelai, penggilingan basah, penyaringan dan pemanasan (Muchtadi dan Sugiyono, 1991 ). Akan tetapi, diperlukan modifikasi pada tahaptahap tersebut agar mutu dari susu kedelai dapat diperbaiki, khususnya terhadap bau langunya. Menurut Shurtleff dan Aoyagi (1984), bau langu dapat dikurangi dengan perlakuan penggilingan dengan menggunakan air panas (hot grind) hingga bubur kedelai mencapai suhu $80^{\circ} \mathrm{C}$, pre-blanch yaitu dengan pembasaan kedelai dengan menggunakan $0.25 \%$ sampai $0.5 \%$ sodium bicarbonate, kemudian dilakukan blanching dengan air mendidih selama 20 menit. Cara lain adalah dengan penghilangan lemak pada kedelai dan vaccum deodorization. Perlakuan-perlakuan tersebut bertujuan untuk menginaktifkan enzim lipoksidase yang akan bereaksi dengan lemak menghasilkan bau langu.

Komponen senyawa sakarida yang terdapat pada susu kedelai terdapat pada tabel berikut:

Tabel 1. Komponen Senyawa Sakarida Susu kedelai

\begin{tabular}{|c|c|}
\hline Sakarida & \% berat kering \\
\hline Arabinosa & 0.01 \\
\hline Ramnosa & 0.50 \\
\hline Fruktosa & 1.15 \\
\hline Galaktosa & 0.40 \\
\hline + Glukosa & - \\
\hline + Manosa & - \\
\hline Sukrosa & 8.14 \\
\hline Selebiosa & 0.45 \\
\hline Galaktobisa & 0.41 \\
\hline Stasiosa & 4.55 \\
\hline Rafinosa & 1.19 \\
\hline
\end{tabular}

Sumber : CRC Critical review in Food Science and Nutrision. Vol. 27. Issue 4 (1988), Author Glesni Mailead \& Jennifer Ames

Yoghurt merupakan minuman tradisional yang berasal dari Bulgaria yang didapat dari susu kambing atau susu sapi yang telah dipanaskan, kemudian diinokulasi pada suhu 40 - $45^{\circ} \mathrm{C}$ dan diinkubasi pada suhu tersebut selama 8 - 10 jam (Matuszewski dan SupinskaJakubowska, 1949 di dalam Oberman, 1985). Yoghurt yang dihasilkan mempunyai konsistensi yang lembut, mempunyai kekentalan yang tinggi dan tidak terdapat butiran-butiran dan tidak berbusa (Oberman, 1985).

Mikroorganisme yang berperan dalam pembentukan yoghurt adalah Lactobacillus bulgaricus dan Streptococcus thermophilus (Koroleva dan Kondratenko, 1978; Rasic dan Kurmann, 1978 di dalam Oberman, 1985). Lactobacillus bulgaricus dan Streptococcus thermophilus merupakan bakteri asam laktat yang tumbuh secara optimum pada suhu 40 $45{ }^{\circ} \mathrm{C}$. Pada awal fermentasi, Streptococcus thermophilus tumbuh dengan cepat dan mengakibatkan akumulasi asam laktat dan asam asetat, asetaldehida, diasetil serta asam format. Adanya zat-zat tersebut dan perubahan potensial oksidasi-reduksi pada medium (yoghurt), merangsang pertumbuhan Lactobacillus bulgaricus. Pada akhir 
fermentasi, yoghurt mempunyai $\mathrm{pH} \mathrm{4,2-4,3}$ (Oberman, 1985). Untuk mendapatkan yoghurt yang mempunyai tekstur dan flavor yang baik, digunakan Lactobacillus bulgaricus dan Streptococcus thermophilus dengan perbandingan 1: 1 (Vedamuthu, 1982).

\section{METODE PENELITIAN}

\section{Bahan dan alat}

Bahan baku yang digunakan dalam penelitian ini adalah susu kedelai, susu skim dan starter Lactobacillus bulgaricus dan Streptococcus thermophillus. Sedangkan bahan kimia yang digunakan untuk analisis adalah larutan glukosa standar, galaktosa standar, sukrosa standar, staciosa standar, asam laktat standar, akuades, asam sulfat 0,009 N, acetonitril, kalsium karbonat, $\mathrm{Pb}$ asetat, natrium oksalat kering, $\mathrm{NaOH} 0.1$ dan $0,2 \mathrm{~N}$, dan indikator phenolftalein.

Alat-alat yang digunakan adalah HPLC, neraca analitik, pemanas (heater), penangas air, inkubator, refrigerator, $\mathrm{pH}$ meter, buret, pipet 1 $\mathrm{ml}$ dan $5 \mathrm{ml}$, water bath $100{ }^{\circ} \mathrm{C}$, sentrifuse, dan berbagai alat gelas yang lazim digunakan dilaboratorium kimia.

\section{Preparasi Sampel}

Susu kedelai (1000 mL) dicampur dengan susu skim sebanyak $70 \mathrm{~g}(7 \% \mathrm{w} / \mathrm{v})$. Campuran homogen kemudian dipanaskan pada suhu $85^{\circ} \mathrm{C}$ selama 30 menit dan didinginkan hingga suhu $37^{\circ} \mathrm{C}$. Setelah itu diinokulasi dengan Lactobacillus bulgaricus dan Streptococcus thermophillus sebanyak $30 \mathrm{~mL}$ $(3 \% \mathrm{v} / \mathrm{v})$ dengan perbandingan $1: 1$, kemudian diinkubasi pada suhu $40^{\circ} \mathrm{C}$ selama 8 jam. Secara ringkas prosedur tersebut dapat dilihat pada bagan alir di bawah ini. Kemudian diulangi prosedur yang sama untuk rasio $L$. bulgaricus dan $S$. thermophillus (1:3)

\section{Analisa Kadar Gula (Metode HPLC)}

HPLC yang digunakan dalam analisa asam adalah HPLC collumn for organic acid Analysis, Ion Exclusion HPX -87 H 300 mm x $7,8 \mathrm{~nm}$, catalog 125-0140 serial 255197, menggunakan kolom aminex, bio rad dan detektor yang digunakan adalah detector refraktif index.

Analisis kadar gula dengan metode HPLC mengikuti prosedur menurut Apriyantono, dkk.
(1989) dengan langkah-langkah sebagai berikut:

1. Sampel ditimbang dengan ketentuan jika dilarutkan dalam air akan memberikan gula pereduksi dengan konsentrasi tidak lebih dari $200 \mathrm{mg} / 25 \mathrm{~mL}$ (biasanya digunakan sebanyak 29 gram sampel dalam $500 \mathrm{~mL}$ larutan).

2. Sampel dipindahkan ke dalam gelas piala $600 \mathrm{~mL}$, ditambahkan 200-300 mL air dan 2 gram $\mathrm{CaCO}_{3}$; dan dididihkan selama 30 menit.

3. Selanjutnya larutan didinginkan dan dipindahkan ke dalam labu ukur $500 \mathrm{~mL}$, kemudian ditambahkan larutan $\mathrm{Pb}$-asetat jenuh sedikit demi sedikit sampai larutan jernih (umumnya dibutuhkan 3-5 mL Pbasetat).

4. Volume larutan ditepatkan sampai tanda tera dan disaring dengan kertas saring Whatman no. 2.

5. Selanjutnya ditambahkan natrium oksalat kering secukupnya $( \pm 1$ gram $)$ untuk mengendapkan semua $\mathrm{Pb}$; dicampur sampai merata, dan disaring kembali. Filtrat yang diperoleh diambil sebanyak $10 \mu \mathrm{L}$ dan diinjeksikan ke HPLC.

6. Digunakan standar glukosa, galaktosa, sukrosa, dan staciosa sebagai pembanding (Sigma).

\section{Analisa Asam Laktat (Metode HPLC)}

Asam laktat dianalisis dengan metode HPLC mengikuti prosedur menurut Marsili, et al. (1981) dengan langkah-langkah sebagai berikut:

1. Sebanyak 5 gram sampel dilarutkan dengan $5 \mathrm{~mL}$ air, ditambahkan $20 \mathrm{~mL}$ asetonitril.

2. Campuran dipindahkan ke dalam tabung sentrifuse $50 \mathrm{~mL}$, dan dikocok selama 1 menit. Kemudian disentrifuse pada 7000 rpm selama 5 menit.

3. Supernatannya diambil $10 \mu \mathrm{L}$ dan diinjeksikan ke HPLC.

4. Sebagai internal standar digunakan asam laktat dan asam piruvat (Sigma).

Spesifikasi HPLC untuk analisa asam laktat sama dengan analisa gula hanya dibedakan pada detectornya, yakni detector UV, model 1305 A dengan panjang gelombang $210 \mathrm{~nm}$.

\section{Analisa Total Asam (Titrasi)}

Analisis total asam ditentukan dengan metode titrasi asam-basa dengan langkahlangkah sebagai berikut : 
1. $10 \mathrm{~mL}$ sampel diencerkan dengan $50 \mathrm{~mL}$ air dan ditambahkan 5 tetes indikator phenolftalein.

2. Sampel dititrasi dengan larutan $\mathrm{NaOH} 0,1$ $\mathrm{N}$ hingga terbentuk warna merah muda yang stabil.

3. kadar total asam ditentukan dengan formula berikut:

$\mathrm{mL}$ titer $\mathrm{x} N$ titer $\mathrm{x} 0,09 \mathrm{x}$

100

$$
\% \text { asam }=\frac{}{\text { berat contoh }(\mathrm{g})}
$$

\section{Rancangan Penelitian}

Analisa data hasil penelitian dilakukan melalui rancangan acak lengkap 2 (dua) faktor, dengan model rancangan sebagai berikut:

$$
\mathrm{Y}_{\mathrm{ijk}}=\mu+\alpha_{\mathrm{i}}+\beta_{\mathrm{j}}+(\alpha \beta)_{\mathrm{ij}}+\varepsilon_{\mathrm{ijk}}
$$

$$
\begin{aligned}
& \text { dimana: } \mathrm{Y}_{\mathrm{ijk}} \quad=\text { nilai pengamatan } \\
& \mu \quad=\text { nilai rataan umum } \\
& \alpha_{i} \quad=\text { pengaruh perlakuan } \\
& \text { rasio starter } \\
& \beta_{\mathrm{j}} \quad=\text { pengaruh perlakuan } \\
& \text { waktu inkubasi } \\
& (\alpha \beta)_{\mathrm{ij}} \quad=\text { pengaruh perlakuan } \\
& \text { rasio starter dan } \\
& \text { waktu inkubasi } \\
& \varepsilon_{\mathrm{ijk}} \quad=\text { galat percobaan }
\end{aligned}
$$

Tabel 2. Hubungan waktu inkubasi dan rasio starter pada pengolahan susu kedelai menjadi yoghurt.

\begin{tabular}{|l|c|c|c|c|c|}
\hline \multirow{2}{*}{$\begin{array}{c}\text { Perban } \\
\text { dingan } \\
\text { starter } \\
(\mathrm{A}) *\end{array}$} & \multicolumn{5}{|c|}{ Waktu inkubasi (jam) } \\
\cline { 2 - 6 } & $\mathrm{B}_{0}$ & $\mathrm{~B}_{1}$ & $\mathrm{~B}_{2}$ & $\mathrm{~B}_{3}$ & $\mathrm{~B}_{4}$ \\
$(2)$ & $(4)$ & $(6)$ & $(8)$ \\
$\mathrm{A}_{1}(1: 1)$ & $\mathrm{A}_{1} \mathrm{~B}_{0}$ & $\mathrm{~A}_{1} \mathrm{~B}_{1}$ & $\mathrm{~A}_{1} \mathrm{~B}_{2}$ & $\mathrm{~A}_{1} \mathrm{~B}_{3}$ & $\mathrm{~A}_{1} \mathrm{~B}_{4}$ \\
$\mathrm{~A}_{2}(1: 3)$ & $\mathrm{A}_{2} \mathrm{~B}_{0}$ & $\mathrm{~A}_{2} \mathrm{~B}_{1}$ & $\mathrm{~A}_{2} \mathrm{~B}_{2}$ & $\mathrm{~A}_{2} \mathrm{~B}_{3}$ & $\mathrm{~A}_{2} \mathrm{~B}_{4}$ \\
\hline
\end{tabular}
* Perbandingan starter (Lactobacillus
Streptococcus thermophillus)

\section{HASIL DAN PEMBAHASAN}

Data yang diperoleh dari penelitian dikelompokkan menjadi dua kelompok Data pertama berupa $\mathrm{pH}$ dan total asam yang diperoleh dari pengukuran $\mathrm{pH}$ meter dan titrasi. Sedangkan data kedua adalah data yang didapatkan dari analisa dengan HPLC. Data perubahan $\mathrm{pH}$ pada yoghurt yang diinkubasi selam waktu total 8 jam adalah:seperti disajikan pada tabel 3, dimana data tersebut merupakan hasil $\mathrm{pH}$ rata-rata dari dua kali pengulangan selama pengukuran.

Tabel 3: Perubahan $\mathrm{pH}$ pada Yoghurt Susu Kedelai

\begin{tabular}{|c|c|c|}
\hline \multirow{2}{*}{$\begin{array}{c}\text { Waktu } \\
\text { (jam) }\end{array}$} & \multicolumn{2}{|c|}{ nilai rata-rata $\mathrm{pH}$} \\
\cline { 2 - 3 } & $\mathrm{A}$ & $\mathrm{B}$ \\
\hline 0 & 6.2 & 6.13 \\
\hline 2 & 6.1 & 6.05 \\
\hline 4 & 5.9 & 5.87 \\
\hline 6 & 5.7 & 5.5 \\
\hline 8 & 5.2 & 5.17 \\
\hline
\end{tabular}

Berdasarkan data tersebut terlihat bahwa dengan peningkatan waktu inkuibasi terjadi penurunan $\mathrm{pH}$ pada kedua jenis variasi starter. A untuk perbandingan L bulgaricus : S.Thermopilus (1:1) sedangkan B adalah L.bulgaricus : S.Thermopilus (1:3)

Dengan adanya perubahan nilai $\mathrm{pH}$ yang terjadi pada setiap skala waktu inkubasi, terlihat bahwa waktu inkubasi mempengaruhi pembentukan asam pada yoghurt. Perubahan pH yang terjadi pada kedua sampel baik sampel A yang menggunakan kombinasi starter ( $L$. Bulgaricus : S. Thermophilus, 1.1) maupun pada sampel B dengan perbandingan starter 1:3.

Dari uji statistik yang menggunakan metode Tukey's Parwise Comparison dengan tingkat kepercayaan 95\% terlihat bahwa untuk sampel A terdapat perbedaan nyata pada waktu antara 0 jam, 6 jam dan 8 jam, pada waktu 0 jam sampai dua jam belum signifikan. Sedangkan untuk sampel B juga memperlihatkan hasil yang sama dimana pada 0 jam sampai 2 jam belum signifikan sedangkan pada $4,6,8$, jam baru berbeda secara signifikan.

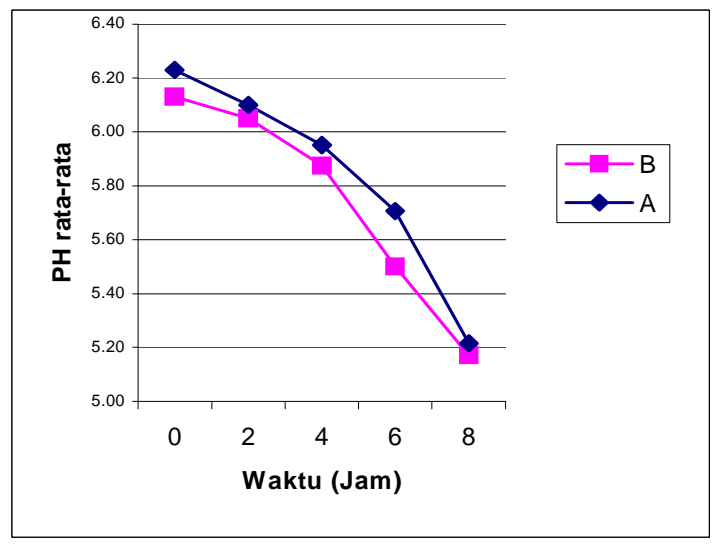

Gambar 1. Hubungan antara waktu inkubasi dengan $\mathrm{pH}$ Yoghurt 
Dengan bertambahnya waktu inkubasi, aktivitas mikroba semakin meningkat dan jumlah mikroba semakin banyak, sehingga mengakibatkan $\mathrm{pH}$ medium menjadi turun. Hal ini membuktikan terjadinya perubahan kimia pada komponen gula menjadi komponen asam.

Walaupun begitu, jenis perbandingan starter yang berbeda ternyata tidak menghasilkan perbedaan penurunan $\mathrm{pH}$ yang signifikan. Dengan demikian jenis starter tidak mempengaruhi aktifitas perubahan komponen gula menjadi komponen asam laktat.

Selain nilai $\mathrm{pH}$, pembentukan asam selama waktu inkubasi dapat diamati dari kenaikan konsentrasi asam pada produk yoghurt yang dihasilkan. Konsentrasi asam merupakan total asam yang diperoleh dari hasil titrasi seperti terlihat pada tabel 4 .

Tabel 4: Total asam yang dihasilkan

\begin{tabular}{|c|c|c|}
\hline \multirow{2}{*}{$\begin{array}{c}\text { Waktu } \\
\text { (jam) }\end{array}$} & \multicolumn{2}{|c|}{ Total Asam (\%) } \\
\cline { 2 - 3 } & A & B \\
\hline 0 & 0.171 & 0.180 \\
\hline 2 & 0.207 & 0.198 \\
\hline 4 & 0.213 & 0.252 \\
\hline 6 & 0.279 & 0.288 \\
\hline 8 & 0.423 & 0.468 \\
\hline
\end{tabular}

Hasil analisa dengan alat HPLC menunjukkan bahwa komponen senyawa asam yang terdapat pada yoghurt adalah senyawa asam laktat dengan konsentrasi yang relatif berbeda pada kedua jenis sampel (tabel 5).

Tabel 5. Konsentrasi asam laktat pada 0 jam dan 8 jam dengan analisa HPLC

\begin{tabular}{|c|c|c|}
\hline \multirow{2}{*}{ Sampel } & \multicolumn{2}{|c|}{ Konsentrasi Asam laktat (gr/L) } \\
\cline { 2 - 3 } & 0 jam & 8 jam \\
\hline $\mathrm{A}(1: 1)$ & 0.2838 & 0.2651 \\
\hline $\mathrm{B}(1: 3)$ & 0.0509 & 0.0583 \\
\hline
\end{tabular}

Konsentrasi asam laktat pada sampel B yang menggunakan perbandingan starter 1:3, mengalami kenaikan dari $0,0509 \mathrm{gr} / \mathrm{L}$ menjadi $0.0583 \mathrm{gr} / \mathrm{L}$. Sedangkan pada sampel A perbandingan starter 1:1 tidak menunjukkan perubahan konsentrasi asam laktat pada waktu inkubasi 0 jam sampai 8 jam. Hal ini sebenarnya berlawanan dengan pengamatan $\mathrm{pH}$ dan total asam yang menunjukkan adanya kenaikan asam. Kondisi ini dikarenakan banyak jenis asam yang terbentuk selama proses pembuatan yoghurt serta karena keterbatasan pada standar yang mengakibatkan analisa HPLC kurang optimal.

Hasil analisa komponen senyawa gula dengan HPLC (tabel 6) menunjukkan adanya dua komponen gula utama yang terdeteksi yaitu sukrosa dan laktosa. Walaupun demikian masih terdapat kemungkinan adanya senyawa gula yang lain yang mungkin tidak terdeteksi karena keterbatasan standar yang digunakan.

Tabel 6. Konsentrasi Sukrosa dan laktosa dari analisa HPLC (mg/L)

\begin{tabular}{|c|c|c|c|}
\hline Sampel & Waktu (jam) & Sukrosa & Laktosa \\
\hline A (1:1) & 0 & 0.0156 & 0.0497 \\
\hline & 8 & 0.0128 & 0.0400 \\
\hline B (1:3) & 0 & 0.0125 & 0.0483 \\
\hline & 8 & 0.0075 & 0.0407 \\
\hline
\end{tabular}

Pada komponen Sukrosa terjadi trend penurunan konsentrasi sukrosa pada kedua sampel baik A maupun B. Hal ini diduga karena proses metabolisme mikroba yang terjadi mengubah sukrosa menjadi asam laktat selama waktu inkubasi. Pernyataan ini juga didukung oleh literatur sebelumnya yang menyebutkan bahwa jenis gula yang mengalami penurunan adalah termasuk sukrosa.

Demikian juga pada laktosa, yang mengalami penurunan konsentrasi dari waktu inkubasi 0 jam sampai 8 jam. Penurunan konsentrasi sukrosa yang terjadi pada kedua sampel menunjukkan tidak ada perbedaan yang signifikan antara perbandingan jumlah starter dengan laju penguraian sukrosa maupun laktosa pada proses pembuatan yoghurt susu kedelai.

Penelitian lebih lanjut perlu dilakukan dengan perbandingan komposisi starter dan jenis mikroba yang lain terutama untuk melihat apakah terdapat pengaruh yang nyata antara kedua parameter tersebut terhadap perubahan kimia yang terjadi selama proses pembuatan yoghurt susu kedelai.

\section{KESIMPULAN}

Berdasarkan hasil analisa data dapat disimpulkan bahwa :

1. Lamanya waktu inkubasi mempengaruhi penurunan $\mathrm{pH}$ dan kenaikan konsentrasi total asam pada proses inkubasi mikroba pada pembuatan Yoghurt dari susu kedelai.

2. Perbandingan jumlah dua starter yang digunakan tidak mempengaruhi proses perubahan komponen gula menjadi asam laktat. 
3. Dari data HPLC terbukti bahwa komponen gula meliputi sukrosa dan laktosa mengalami perubahan dengan penurunan konsentrasi pada waktu 0 jam dan 8 jam.

4. Jenis asam yang menjadi produk dari proses pembuatan yoghurt adalah asam laktat, dimana komponen tersebut mengalami peningkatan konsentrasi dari 0 jam sampai 8 jam, pada sampel $B$ yang perbandingan starternya $1: 3$

\section{DAFTAR PUSTAKA}

1. Apriyantono, A., Farziaz, D., Puspitasari, N. L., Sedarnawati dan Budiyanto, S., 1989, Petunjuk Laboratorium Analisis Pangan, PAU Pangan dan Gizi, IPB Bogor.

2. Belizt, H.D. and Grosch W., 1999, Food Chemistry, Second edition, DpringerVerlag, Berlin, 493.

3. Kannel, W.B., et al., 1984, Optimal Resources for Primary Prevention of Anthero-sclerotic diseases, Circulation, 70157A.

4. Marsili, R.T., Ostapenko, H., Simmons, R.E., and Green, D.E., 1981, High Performance

5. Liquid Chromatographic Determination of Organic Acids in Dairy Products, Journal of Food Science, 46, p.52-57.

6. Muchtadi, T.R. dan Sugiyono. 1991. Petunjuk Laboratorium Teknologi Pengolahan Pangan Nabati. Pusat Antar
Universitas IPB, Bogor.

7. Oberman, H., 1985. Fermented Milk. Di dalam Wood, B.J.B. Microbiology of Fermented Foods. Elsevier Applied Science Publisher, London.

8. Salminen, S., Ouwehand, A., Benno, Y. and Lee YK., 1999, Probiotics: How Should they be defined?, Trends Food Sci Tech., 10:107-110.

9. Shurtleff, W. dan Aoyagi, A., 1984. Tofu and Soymilk Production : A Craft and Technical Manual (2 ${ }^{\text {nd }}$. Ed.). Soyfood Center, Lafayette.

10. Sirait, C.H., 1984, Proses Pengolahan susu Menjadi Yoghurt. Wartazoa, Pusat Penelitian dan Pengembangan Peternakan, Bogor, Vol: 1: 4.

11. Vedamuthu, E.R., 1982. Fermented Milks. Di dalam Rose, A.H. Economic Microbiology. Academic Press Inc., London.

12. Wollowski, I., Ji, S.T., Bakalinsky, A.T., Neudecker, C. and Pool-Zobel, B.L., 1999, Bacteria used for the production of yoghurt inactivate carcinogens and prevent DNA damage in the colon of rat, Journal Nutrition, 129:77-82. 